\title{
PERUBAHAN KADAR SITOKIN DAN MOLEKUL AGREGASI PADA BERBAGAI TINGKAT TROMBOSITOPENIA PADA DEMAM BERDARAH DENGUE
}

\section{(THE CONCENTRATION CHANGES OF CYTOKINES AND AGGREGATION MOLECULES IN DIFFERENT LEVELS OF THROMBOCYTOPENIA IN DENGUE HEMORRHAGIC FEVER)}

\author{
Djoni Djunaedi \\ Sie Tropik Infeksi Lab. IPD Fakultas Kedokteran Universitas Brawijaya Malang
}

\begin{abstract}
The uncovering of the changes in the concentration of aggregation molecules (VWF, PGI $)_{2}$ and cytokines (TNF $\alpha, I L-1 \beta$, IL-6) in different levels of thrombocytopenia in DHF patients can be used as the basis in predicting the occurrence of thrombocytopenia. A prospective-observational study was undertaken utilizing a 3-day sequentially drawn vein blood of inclusive DHF patients. The TNFa, IL-1 $\beta$ and IL-6 test was conducted utilizing the quantikine high sensitivity human cytokine immunoassay, and the VWF and $P G I_{2}$ test was conducted utilizing the ELISA procedure. The multivariate and discriminant analyses tests on the deltas between day 1 and 2 observations, and between day 2 and 3 observations of the 6 variables showed Wilks' Lambda $=0.638$ with $p=0.008$ and platelets and vWF as the most powerful discriminating variable (70.5.\%). The findings of this study indicated that in DHF patients (1) the changing of the concentration of TNF $\alpha$, IL-1 $\beta$ and IL-6 cytokines do not play a significant role in the mechanism of platelets aggregation, (2) platelets count decreases in a condition in which vWF facilitated platelets aggregation, (3) the changing of a positive contribution of vWF causes a determination of the process of platelets aggregation, and (4) a positive changing of vWF's concentration can be used as a prognostic indicator of a negative changing of platelets count..
\end{abstract}

Key words: Dengue Hemorrhogic Fever, thrombocytopenia, vWF

\section{PENDAHULUAN}

Insidensi dan penyebaran penyakit demam berdarah dengue (DBD) semakin meningkat dan meluas dari tahun ke tahun (1). Selain berdasarkan kriteria WHO, diagnosis DBD perlu dikonfirmasi dengan penemuan IgM anti dengue positif atau isolasi virus dengue $(2,3,4,5)$. Perdarahan yang terjadi pada penderita DBD akibat agregasi trombosit dapat berkembang menuju DIC dan dapat berakhir dengan kematian $(6,7,8)$. Perkembangan perdarahan tersebut sulit diprediksi dan jika hal itu diketahui, perjalanan penyakit sudah pada tingkat lanjut. Oleh karena itu pengungkapan pengaruh perubahan kadar molekul agregasi vonWillebrand factor, Prostaglandin $I_{2}$ (vWF, PGI $)$ terhadap kejadian agregasi trombosit yang menyebabkan trombositopenia pada penderita DBD dapat digunakan sebagai prognostik indikator perdarahan akibat trombositopenia pada penyakit DBD.

Trombositopenia pada penderita DBD diduga terjadi melalui mekanisme kompleks imun yang didapatkan pada permukaan trombosit $(9,10)$ dan akibat penurunan produksi trombosit oleh sumsum tulang, peningkatan destruksi

Jurnal Kedokteran Brawijaya, Vol. XXI, No.1, April 2005 Korespondensi: Djoni Djunaedi; Laboratorium IImu Penyakit Dalam FK Unibraw, JI. Veteran Malang 65145; telp. 0341357663 trombosit di reticulo endothelial system (RES), serta agregasi trombosit akibat endotel yang teraktivasi (11). Endotel vaskuler yang teraktivasi akibat infeksi virus dengue memberi peluang kepada trombosit dalam sirkulasi pembuluh darah untuk berinteraksi dengan kolagen dalam lapisan sub-endotel yang kemudian memicu agregasi trombosit dan bermuara pada trombositopenia $(9,12)$. Para peneliti telah membuktikan bahwa pada penderita aterosklerosis dan trombosis peningkatan produksi molekul protrombosis vWF dan penurunan produksi molekul antitrombosis $\mathrm{PGI}_{2}$ oleh endotel yang teraktivasi memicu agregasi trombosit $(13,14,15,16,17,18)$. Diduga agregasi trombosit pada penderita DBD juga dipicu oleh perubahan kadar vWF dan $\mathrm{PGI}_{2}$ akibat endotel yang teraktivasi oleh sitokin yang dihasilkan oleh monosit yang mengandung virus DBD dan $T$ helper-1 (TH-1) yang berfungsi sebagai stress cells. Pada penderita DBD, peran sitokin terutama tumor necrotizing factor- $\alpha$ (TNF $\alpha$ ), interleukin-1 $\beta$ (IL-1 $\beta)$, dan interleukin-6 (IL-6) dalam menyebabkan aktivasi endotel $(12,19,20,21,22)$ telah diungkap, tetapi perubahan kadar sitokin dan perubahan kadar molekul agregasi akibat endotel yang teraktivasi pada berbagai tingkat trombositopenia belum pernah diungkap. Dengan demikian tujuan penelitian ini adalah: Membuktikan perbedaan perubahan kadar TNF $\alpha, \mathrm{IL}-1 \beta, \mathrm{IL}-6, \mathrm{vWF}$, dan $\mathrm{PGI}_{2}$ pada 
berbagai tingkat trombositopenia penderita $\mathrm{DBD}$ pada pemeriksaan hari 1-2 dan hari 2-3.

\section{METODE}

Penelitian prospective-observasional dilakukan kepada penderita DBD yang dilibatkan dalam penelitian ini. Setiap hari sejak hari pertama sampai dengan hari ketiga perawatan dilakukan pengukuran kadar IL-1 $\beta$, IL-6, dan vWF dalam serum, pengukuran kadar TNF $\alpha$ dan $\mathrm{PGI}_{2}$ dalam plasma sitrat, dan pengukuran jumlah trombosit darah tepi. Deteksi IgM dan IgG anti dengue dikerjakan pada hari ke-5 perawatan. Data yang diperoleh dikelompokkan ke dalam perubahan data yang diamati pada hari pertama dan ke-2, dan perubahan data yang diamati pada hari ke-2 dan ke-3 untuk kemudian dilakukan analisis multivariat dan diskriminan terhadap perubahan berbagai variabel penelitian dalam ke-2 kelompok tersebut.

\section{Populasi, Sampel dan Bahan Penelitian}

Populasi dalam penelitian ini adalah semua penderita yang didiagnosis sebagai DBD berdasarkan kriteria WHO yang dirawat di bangsal IImu Kesehatan Anak dan IImu Penyakit Dalam Rumah Sakit Umum Daerah dr. Soetomo Surabaya dan Rumah Sakit Umum Daerah dr. Saiful Anwar Malang, serta yang dirawat di berbagai Rumah Sakit swasta (Panti Waluya, Panti Nirmala, dan Lavallette) di Malang.

Sampel atau penderita yang selanjutnya dilibatkan dalam penelitian ini adalah populasi yang memenuhi kriteria jika dikonfirmasi dengan dengue fever rapid test, tidak mendapat pengobatan imunosupresif sebelum dan selama penelitian berlangsung, dan penderita atau orang tua penderita menyatakan bersedia dilibatkan dalam penelitian. Selain itu penderita juga bebas dari hipertensi, diabetes mellitus, hamil, trauma, rokok, riwayat diatesis hemoragika dan tindakan pembedahan.

Bahan yang dipakai dalam penelitian ini adalah darah yang diambil dari vena setiap sampel, larutan natrium sitras, EDTA cair, berbagai reagen khusus untuk keperluan pemeriksaan IgM, IgG, TNF $\alpha$, IL-1 $\beta$, IL-6, vWF dan $\mathrm{PGI}_{2}$.

\section{Identifikasi, Definisi Operasional dan Cara Pemeriksaan Variabel Penelitian}

Dalam penelitian ini, sitokin (TNF $\alpha$, IL-1 $\beta$, IL-6) dan molekul agregasi (vWF dan $\mathrm{PGI}_{2}$ ) ditempatkan sebagai variabel independen, sedangkan hitung trombosit darah tepi ditempatkan sebagai variabel dependen.

1. vWF (vonWillebrand factor): suatu high molecular weight glycoprotein yang disintesis oleh sel endotel dan dijumpai dalam peredaran darah. Pemeriksaan kadar vWF dikerjakan melalui prosedur enzyme-linked immunosorbent assay (ELISA) dengan detection limit $0,5 \%$ vWF
2. $\mathrm{PGI}_{2}$ (prostaglandin $I_{2}$ ): derivat yang disekresi oleh endotel, dibentuk dari arachidonic acid yang mengalami proses cyclooxygenases dan dijumpai dalam peredaran darah. Pemeriksaan kadar $\mathrm{PGI}_{2}$ juga dikerjakan dengan menggunakan prinsip ELISA.

3. TNF $\alpha$ (Tumor Necrotizing Factor $\alpha$ ): suatu jenis sitokin yang terutama diproduksi oleh fagosit mononuklear yang teraktivasi dan menstimulasi endotel untuk mengekspresikan molekul agregasi. Pemeriksaan kadar TNF $\alpha$ dikerjakan dengan menggunakan quantikine high sensitivity human TNF $\alpha$ immunoassay dengan kepekaan antara $0,06 \mathrm{pg} / \mathrm{mL}-0,32 \mathrm{pg} / \mathrm{mL}$ (rata-rata $0,12 \mathrm{pg} / \mathrm{mL}$ ).

4. IL-1ß (Interleukin-1ß): suatu jenis sitokin yang terutama diproduksi oleh fagosit mononuklear yang teraktivasi dan menginduksi molekul agregasi yang dilepas oleh endotel. Pemeriksaan kadar IL-1 $\beta$ dikerjakan dengan menggunakan quantikine high sensitive human IL-1 $\beta$ immunoassay dengan kepekaan kurang dari $0,1 \mathrm{pg} / \mathrm{mL}$.

5. IL-6 (Interleukin-6): suatu jenis sitokin yang diproduksi oleh fagosit mononuklear dan endotel yang teraktivasi dan menstimulasi pertumbuhan antibodi humoral. Pemeriksaan kadar IL-6 dikerjakan dengan menggunakan quantikine high sensitive human IL-6 immunoassay dengan kepekaan kurang dari $0,094 \mathrm{pg} / \mathrm{mL}$.

6. IgG (immunoglobulin $\mathrm{G}$ ) dan IgM (immunoglobulin $\mathrm{M}$ ) anti dengue: jenis molekul glikoprotein yang diproduksi oleh limfosit $B$ yang mengikat antigen (virus DBD). Keduanya berbeda dalam hal struktur heavy chain constant regions-nya. Pemeriksaan IgM dan IgG anti dengue dikerjakan dengan menggunakan dengue fever rapid test.

7. Trombositopenia: keadaan di mana jumlah trombosit darah tepi $\leq 100.000$ per $\mathrm{mm}^{3}$. Pemeriksaan ini dikerjakan dengan menggunakan piranti haematology automatic analyzer yang bertumpu pada prinsip impedancy.

8. Perubahan kadar adalah besar satuan kadar berbagai molekul yang tidak sama dari waktu ke waktu selama penelitian berlangsung.

\section{Cara Analisis Data Penelitian}

Untuk menentukan perubahan berbagai variabel penelitian dalam pengamatan sekuensial selama 3 hari tersebut, dilakukan perhitungan delta terhadap setiap variabel penelitian antara pengamatan hari pertama dan ke2 (P 1-2), dan antara hari ke-2 dan ke-3 (P 2-3). Untuk menentukan variabel pembeda yang paling dominan dilakukan analisis diskriminan. 


\section{HASIL PENELITIAN}

\section{Perubahan Sitokin dan Molekul Agregasi pada Pengamatan 1-2 dan Pengamatan 2-3}

Dalam penelitian ini dilibatkan 22 penderita DBD yang memenuhi kriteria penelitian. Sejalan dengan tujuan penelitian, dilakukan perhitungan perubahan (delta, selisih) antara masing-masing variabel penelitian (hitung trombosit darah tepi, kadar TNF $\alpha, I L-6, I L-1 \beta$, vWF dan $\mathrm{PGI}_{2}$ ) yang diperoleh pada pengamatan hari pertama dan ke-2 (P 1-2) dan perhitungan perubahan antara masing-masing variabel penelitian yang diperoleh pada pengamatan hari ke-2 dan ke-3 (P 2-3). Dengan demikian diperoleh 2 kelompok data penelitian, yaitu kelompok data penelitian $\mathrm{P}$ 1-2 dan $\mathrm{P}$ 2-3. Rerata dan standar deviasi berbagai variabel penelitian pada P 1-2 dan P 2-3 dapat dilihat pada Tabel 1.

Tabel 1. Rerata dan Standar Deviasi Delta Berbagai Variabel Penelitian Pada P 1-2 Dan P 2-3

\begin{tabular}{lcccc}
\hline \multirow{2}{*}{ Variabel } & \multicolumn{3}{c}{ Kelompok } \\
\cline { 2 - 5 } & Rerata & Stand.dev & Rerata & Stand.dev \\
\cline { 2 - 5 } & $-18818,18$ & 24627,9678 & $-50681,82$ & 37950,3264 \\
\hline D-Tromb & 2,3873 & 14,3893 & $-2,2900$ & 9,0557 \\
\hline D-TNF $\alpha$ & $-6,84 \mathrm{E}-02$ & 1,1610 & $-0,7514$ & 1,3652 \\
\hline D-IL-1 & 1,0768 & 8,9789 & 1,1059 & 5,9315 \\
\hline D-IL-6 & $-3,5909$ & 46,7879 & 24,4545 & 38,1959 \\
\hline D-VWF & $-0,2041$ & 0,5601 & $-1,23 E-02$ & 0,5392 \\
\hline D-PGI2 & & & & \\
\hline
\end{tabular}

Keterangan:

D: Delta

Hasil analisis multivariat terhadap perubahan ke-6 variabel penelitian pada P1-2 dan P 2-3 menunjukkan Wilks' Lambda $=0.638$ dengan $p=0.008$. Ini berarti ada perbedaan sitokin dan molekul agregasi pada ke-2 kelompok tersebut. Variabel pembeda yang paling kuat adalah trombosit $(F=10.913$ dengan $p=0.002)$ dan $v W F(F=4.743$ dengan $p=0.035$ ) dengan koefisien fungsi diskriminan Fisher sebagaimana nampak pada Tabel 2. Hasil analisis lebih lanjut menunjukkan bahwa kekuatan pembeda ke-2 variabel tersebut adalah sebesar $70.5 \%$.

Tabel 2. Koefisien Fungsi Diskriminan Fisher pada P 1-2 dan P 2-3

\begin{tabular}{lcc}
\hline & \multicolumn{2}{c}{ Kelompok } \\
\cline { 2 - 3 } Variabel & P 1-2 & P 2-3 \\
\hline D-Tromb & $-1,839 \mathrm{E}-05$ & $-5,313 \mathrm{E}-05$ \\
\hline D-VWF & $-1,463 \mathrm{E}-05$ & $1,905 \mathrm{E}-02$ \\
\hline (konstan) & $-0,866$ & $-2,273$ \\
\hline
\end{tabular}

Keterangan:

D- : Delta atau selisih perubahan besaran nilai sesuatu variable yang diperoleh pada pengukuran hari pertama dan hari berikutnya. Jika besaran nilai variable pada hari berikutnya lebih besar daripada hari sebelumnya, maka selisih perubahan tersebut ditandai dengan (-) atau negative. Sebaliknya, jika besaran nilai variable pada hari berikutnya lebih kecil daripada hari sebelumnya maka selisih perubahan tersebut tanpa ditandai dengan (-).

E-02 : Simbul yang menunjukkan tingkatan presisi yang digunakan dalam proses perhitungan; jumlah digit tidak dicetak melainkan disimpan dalam memory komputer. Nilai -6.84E-02 artinya $-0.0684 ;-1.839 E-05$ artinya -0.00001839

\section{Pola Variabel Trombosit dan vWF pada Pengamatan 1-2 dan Pengamatan 2-3}

Pola variabel trombosit dan VWF pada P 1-2 dan P 23 dikerjakan dengan memasukkan nilai rerata trombosit dan vWF sebagaimana nampak pada Tabel 3 di masing-masing kelompok ke dalam fungsi diskriminan Fisher yang sesuai sehingga diperoleh skor diskriminan yang digunakan sebagai basis penyusunan pola variabel trombosit dan vWF seperti nampak pada bagan 1 .

\section{Tabel 3. Rerata dan Standar Deviasi Variabel Trombosit} dan vWF pada P 1-2 Dan P 2-3

\begin{tabular}{lcccc}
\hline & \multicolumn{4}{c}{ Kelompok } \\
\hline \multirow{2}{*}{ Variabel } & \multicolumn{2}{c}{ P 1-2 } & \multicolumn{2}{c}{ P 2-3 } \\
\cline { 2 - 5 } & Rerata & Stand.dev & Rerata & Stand.dev \\
\hline Tromb & 0,3461 & 0,4529 & 2,6927 & 2,0163 \\
\hline VWF & $5,253 \mathrm{E}-05$ & $6,845 \mathrm{E}-04$ & 0,4659 & 0,7276 \\
\hline
\end{tabular}




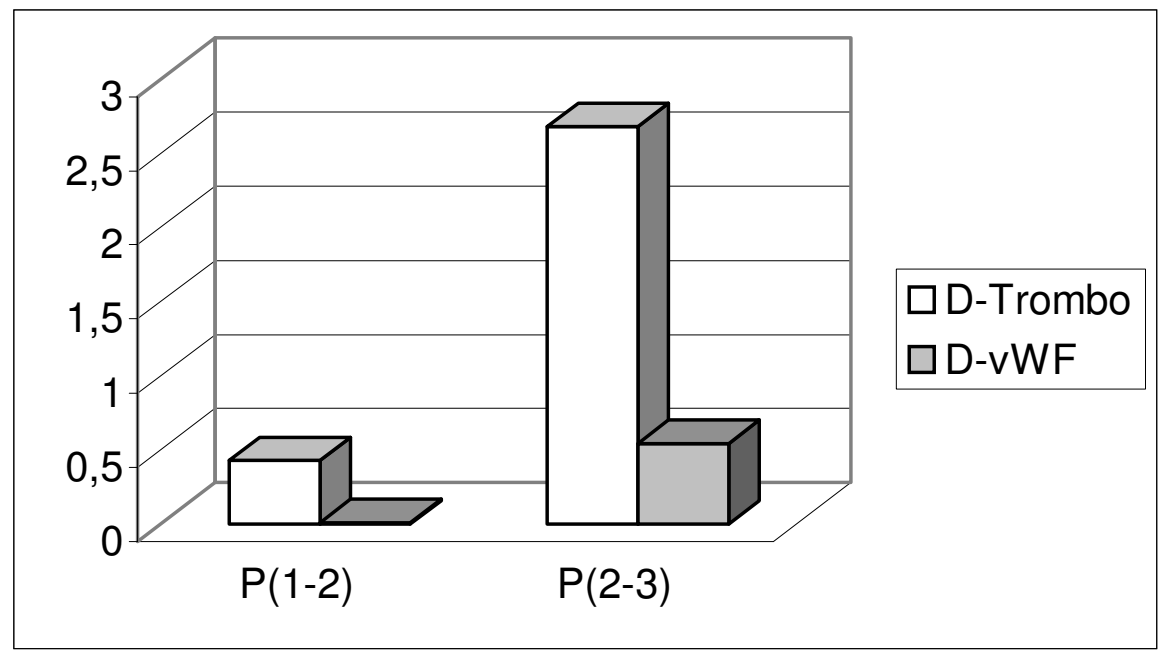

\section{Bagan 1. Pola Perubahan Peran Trombosit dan vWF pada P1-2 dan P2-3 Terhadap Kejadian Agregasi Trombosit}

\section{DISKUSI}

Dalam penelitian ini ditemukan jumlah trombosit paling rendah pada pengamatan hari pertama dan paling tinggi pada pengamatan hari ke-3. Ini berarti jumlah trombosit yang mengalami agregasi pada awal penyakit cukup banyak dan makin berkurang sejalan dengan kesembuhan penyakit.

Kadar TNF $\alpha$ ditemukan menurun pada pengamatan hari ke-2 dan meningkat pada hari ke-3. Kadar TNF $\alpha$ yang ditemukan dalam jumlah besar pada fase awal penyakit DBD nampaknya berperan sebagai stresor terhadap endotel untuk mensekresi sejumlah besar molekul proagregasi vWF. Penurunan kadar TNF $\alpha$ dan kenaikan jumlah trombosit menunjukkan penyakit DBD sedang menuju kesembuhan.

Kadar IL-1 $\beta$ ditemukan meningkat pada pengamatan hari ke-2 dan 3. Secara teoretik peningkatan kadar sitokin menyebabkan aktivasi sel endotel yang diikuti oleh sekresi molekul agregasi vWF dan penurunan jumlah trombosit. Dalam penelitian ini peningkatan kadar TNF $\alpha$ dan IL-1 $\beta$ yang ditemukan pada fase penyembuhan penyakit justru diikuti oleh penurunan kadar vWF dan kenaikan mencolok jumlah trombosit. Kombinasi TNF $\alpha$ dan IL-1 tidak secara signifikan memicu sekresi molekul vWF dari endotel, namun penambahan trombin ke dalam kombinasi tersebut menghasilkan potensiasi sekresi vWF sebesar tiga kali $(23,24)$. Diduga peningkatan kadar TNF $\alpha$ dan IL-1 $\beta$ pada fase penyembuhan penyakit yang diikuti oleh penurunan kadar vWF disebabkan oleh kehadiran trombin pada fase ini tidak cukup banyak untuk membentuk kombinasi dengan TNF $\alpha$ dan IL-1 dalam memicu sekresi molekul vWF. Sedangkan kadar TNF $\alpha$ dan vWF yang ditemukan dalam jumlah besar pada fase awal penyakit diduga disertai dengan kehadiran trombin dalam jumlah cukup (dalam penelitian tidak diukur).

Kadar IL-6 ditemukan meningkat pada pengamatan hari ke-2 dan 3 . Peningkatan kadar IL-6 dihubungkan dengan berat penyakit yang ditandai dengan demam tinggi (25) diduga terjadi melalui induksi fase akut protein dalam hati yang dikenal dengan molekul pirogen. Hal tersebut terjadi pada keadaan sepsis akibat infeksi bakteri, sedang pada DBD IL-6 memberi dampak yang ringan (26). Pada penelitian ini juga tidak nampak peran IL-6. Hal tersebut karena peningkatan kadar IL-6 masih berada dalam batas normal. Bertolak dari kajian di depan, dalam penelitian ini

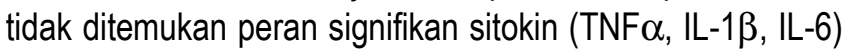
dalam mekanisme agregasi trombosit.

Pola peningkatan $\mathrm{PGI}_{2}$ dalam penelitian sekuensial ini diikuti oleh pola peningkatan trombosit pada fase menuju kesembuhan. Artinya, peningkatan $\mathrm{PGI}_{2}$ diikuti oleh penurunan proses agregasi trombosit. Temuan ini mengisyaratkan perlunya dipertimbangkan pemberian $\mathrm{PGI}_{2}$ pada penderita DBD dengan kecenderungan penurunan jumlah trombosit.

Secara teoretik, peningkatan kadar vWF diikuti oleh penurunan jumlah trombosit dan sebaliknya. Namun dalam penelitian ini, ditemukan fase di mana peningkatan kadar vWF diikuti oleh peningkatan jumlah trombosit. Dalam keadaan teraktivasi secara akut, endotel mensekresi molekul vWF polimer dan molekul vWF propeptide $(27,28)$. Dalam proses agregasi, molekul vWF polimer mempunyai kemampuan lebih tinggi dibandingkan dengan molekul vWF propeptide. Dalam penelitian ini nampaknya vWF yang disekresi pada fase awal DBD mempunyai kualitas yang lebih baik dibandingkan dengan kualitas VWF yang disekresi pada fase berikutnya sehingga peningkatan kadar 
vWF tidak diikuti oleh peningkatan agregasi trombosit atau penurunan jumlah trombosit.

Pada fase penyembuhan ditemukan penurunan kadar vWF, peningkatan kadar $\mathrm{PGI}_{2}$ dan peningkatan jumlah trombosit. Kejadian tersebut menunjukkan bahwa penurunan kadar vWF dan peningkatan kadar $\mathrm{PGI}_{2}$ berperan dalam penurunan dan penghentian proses agregasi trombosit. Kejadian ini bersama-sama dengan pelepasan trombosit baru dari sumsum tulang berakhir pada peningkatan hitung trombosit darah tepi.

Penurunan kadar vWF menyebabkan peningkatan pelepasan sitokin khemotaktik IL-8 (29). Kehadiran sitokin khemotaktik famili C-X-C chemokine yang diwakili oleh IL-8 dan famili C-C chemokine yang diwakili oleh monocyte chemotactic peptide-1(MCP-1) ditemukan pada proses inflamasi yang melibatkan netrofil dan limfosit $(30,31)$. Dalam famili C-X-C chemokine dikenal sitokin khemotaktik stromal cell-derived factor-1 (SDF-1) dan pada trombosit ditemukan reseptor SDF-1 (32). Jika reseptor tersebut berinteraksi dengan sitokin khemotaktik golongan C-X-C maka trombosit akan mengalami aktivasi. Oleh karena IL-8 termasuk golongan C-X-C chemokine maka IL-8 dapat berinteraksi dengan trombosit melalui reseptor SDF-1.

Penurunan kadar vWF yang dikuti oleh peningkatan jumlah trombosit nampaknya berlangsung melalui pengaruh khemotraktan IL-8, bukan melalui pengaruh trombopoeitin (TPO). Diduga peningkatan kadar IL-8 meningkatkan khemotaktik trombosit melalui reseptor SDF-1 sehingga sumsum tulang melepaskan trombosit ke darah tepi dan terjadi peningkatan trombosit darah tepi secara cepat.

\section{KESIMPULAN}

Berdasarkan temuan dan diskusi dalam penelitian ini, kesimpulan yang dapat dikemukakan adalah:
1. Sitokin TNF $\alpha$, IL-1 $\beta$ dan IL-6 tidak menunjukkan peran yang signifikan pada mekanisme agregasi trombosit.

2. Infeksi virus DBD menimbulkan respons imun (monosit, $\mathrm{TH}-1$ dan $\mathrm{TH}-2$ ) dengan akibat terjadi peningkatan kadar TNF $\alpha, \quad$ IL-1 $\beta$ dan IL-6 yang selanjutnya merupakan stresor terhadap sel endotel. Akibat dari endotel yang terjejas akan disekresi molekul vWF dan $\mathrm{PGI}_{2}$. Pada keadaan di mana molekul vWF memfasilitasi agregasi trombosit, maka seperti nampak pada pola pengamatan 1-2, jumlah trombosit akan menurun.

3. Selanjutnya pada pengamatan 2-3 di mana terjadi perubahan berupa peningkatan menyolok hitung trombosit, nampak bahwa perubahan molekul vWF memberikan kontribusi positif yang berarti proses agregasi trombosit berhenti.

4. Perubahan positif molekul vWF dapat digunakan sebagai prognostik indikator terhadap perubahan negatif hitung trombosit.

\section{SARAN}

Saran yang dapat dikemukakan adalah:

1. Penelitian empirik untuk mencegah agregasi trombosit dengan pemberian molekul antibodi-anti vWF diikuti pemberian molekul $\mathrm{PGI}_{2}$ pada penderita $\mathrm{DBD}$ fase akut dengan kecenderungan trombositopenia.

2. Pemeriksaan kadar sitokin dan molekul agregasi perlu dilakukan secara sekuensial terhadap penderita DBD segera setelah dugaan diagnosis DBD ditetapkan dan dalam kurun waktu lebih dari 3 hari pengamatan.

3. Untuk membuktikan peran trombin dalam kombinasi dengan TNF $\alpha$ dan IL-1 $\beta$ dalam meningkatkan sekresi vWF oleh endotel, diperlukan penelitian yang melibatkan trombin sebagai salah satu variabel.

\section{DAFTAR KEPUSTAKAAN}

1. Sutaryo. An Overview of DHF in Indonesia. Work Shop in Molecular Biology. Yogyakarta 9 -19 Sept 1997

2. Daniel DP. Dengue Fever. eMedicine 2002: http://www.emedicine.com/emerg/topic124.htm

3. Kuno G. An ELISA Procedure For the Diagnosis of Dengue Infections. J Virol Methods 1991; 33: 101-113

4. $\quad$ Lam SK. Rapid Dengue Diagnosis and Interpretation. Malaysia: J Pathol 1993; 15: 9-12

5. Vorndam V, Kuno G. Laboratory Diagnosis of Dengue Virus Infection. In (Gubler DJ, Kuno G. eds). Dengue and Dengue Hemorrhagic Fever. Wallingford: Cab International; 1997; 313-333

6. Hadinegoro SRS. Dengue Shock Syndrome, Clinical Manifestation, Management and Outcome. International Seminar on DF/DHF: New Strategy in Controlling and Prevention of DF/DHF in South East Asia. Surabaya 2829 Oktober 1999

7. Lum LCS. Determinants of Outcome in Severe DHF. International Seminar on DF/DHF: New Strategy in Controlling and Prevention of DF/DHF in South East Asia. Surabaya 28-29 Oktober 1999

8. Suharti C. Dengue Infection: Clinical Features in Shock and Non-shock Patients. International Seminar on DF/DHF: New Strategy in Controlling and Prevention of DF/DHF in South East Asia. Surabaya 28-29 Oktober 1999

9. Funahara Y. Three Posible Triggers to Induce Thrombocytopenia in Dengue Virus Infection. South East Asia J Trop Med Pub Hlth 1987; 18(3): 351-355 
10. Suvatte V. Immunological Aspects of Dengue Hemorrhagic Fever. Studies in Thailand. South East Asia J Trop Med Pub Hlth 1987; 18(3): 312-315

11. Sugianto D. Perubahan Jumlah Trombosit pada DBD. CDK. 1994; 92: 14-18

12. Anderson R. Activation of Endothelial Cells via Antibody-enhanced Dengue Virus Infection of Peripheral Blood Monocytes. Journal of Virology 1997; 71(16): 4226-4232

13. Bell W. Thrombotic Thrombocytopenic Purpura. JAMA 1998; 265(1): 91-93

14. Coller BS. Role of Platelets in Thrombolytic Therapy. In: Harbr, E., Braunwald, E. eds. Thrombolysis: Basic Consideration and Clinical Progress. St. Louis: Mosby; 1991.

15. Cotran RS, Kumar V, Collins T. Robin's Pathologic Basis of Diseases. $6^{\text {th }}$ ed. Philadelphia: W.B. Saunders Company; 1999: 1-92

16. Holvoet P, Collen D. Thrombosis ans Atherosclerosis. Current Opninion in Lipidology. 1997; 8: 320-328

17. Lip GYH, Blann AD. vonWillebrand Factor and Its Relevance to Cardiovascular Disorders. Br Heart J 1995; 74: 580-583

18. Vischer UM. Acute vonWillebrand Factor Secretion from the Endothelium in Vivo: Assessment Through Plasma Propeptide (vWF:AgIl) Levels. F.K. Schattauer Verlagsgesellschaft mbH. 1997; 77(2): 387-393

19. Bethell DB. Pathofisiologic and Prognostic Role of Cyrokines in DHF. J of Inf Dis 1998; 177: 778-782

20. Hadinegoro SRS. Telaah Endotoksemia pada Perjalanan Penyakit DBD: Perhatian Khusus pada Syok, Produksi TNFa, Interleukin-6, dan Sebagai Faktor Prediktor DBD Berat. [Disertasi]. Jakarta:U.I. 1996

21. Kurane I. Antibody Dependent Enhancement of Infection. eVirology 2002: http://www.science.mcmaster.ca/Biology/Virology/23/scott.htm

22. Suharti C. Dengue Hemorrhagic Fever in Indonesia: The Role of Cytokines in Plasma Leakage, Coagulation and Fibrinolysis. Nijmegen: Nijmegen University Press. 2001.

23. Paleolog EM. Differential Regulation by Cytokines of Constitutive and Stimulated Secretion of vWF from Endothelial Cells. Blodd 1990;: 75(3): 688-695

24. Fajardo LF. Award Articles and Special Report: The Complexity of Endothelial Cells. Am J Clin Pathol 1989; 92: 241-250

25. Livingstone. Modulation of The Function of Dengue Specific Human CD8+ Cytotoxic T Cell Clone by IL-2, IL-6 and IFNy. Immunol Invest. 1995; 24: 619-629

26. Juffrie M. Immune Response in Dengue Virus Infection. 4th Course on Immunology: Tropical Inf. Dis. Yogyakarta 22-25 April 2002

27. Mannucci PM. vWF a Marker of Endothelial Damage? Arteroscler Thromb Vasc Biol. 1998; 18: 1359-1362

28. Wagner DD, Bonfanti R. vWF and The Endothelium. Mayo Clin. Proc. 1991; 66: 621-627

29. deWitt. vonWillebrand Factor Targets IL-8 to Weibel-Palade Bodies in An Andothelial Cell Line. Exp Cell Res 2003; 286(1): 67-74

30. Hachicha M. Inflammatory Microcrystals Differentially Regulate the Secretion of Macrofage Inflammatory Protein 1 and Interleukin 8 by Human Neutrophils: A Possible Mechanism of Neutrophil Recruitment to Sites of Inflammation in Synovitis. J of Exp Medicine 1995; 182: 2019-2025

31. Lieber JM. Production of IL-8 and Monocyte Chemotactic Peptide-1 by Peripheral Blood Monocytes: Disperate Responses to Phytohemagglutinin and Lipopolysaccharide. J Immunol 1994; 152(1): 241-249

32. Younes SA. The Stromal Cell-derived Factor-1 Chemokine Is A Potent Platelet Agonist Highly Expressed in Atherosclerotic Plaques. Circ Res. 2000; 86: 131-138 
16 Jurnal Kedokteran Brawijaya, Vol. XXI, No. 1, April 2005 